NAKHODA:

JURNAL

ILMU PEMERINTAHAN
NAKHODA: JURNAL ILMU PEMERINTAHAN

Edisi Januari - Juni 2019 Volume: 18 Nomor: 1

ISSN : 1829-5827 | E-ISSN : 2656-5277

DOI : https://doi.org/10.35967/jipn

https://nakhoda.ejournal.unri.ac.id/index.php/JIPN

\title{
LEMBAGA ADAT DI DAERAH ALIRAN SUNGAI SINGINGI
}

\author{
Adlin $^{1}$, Ali Yusri ${ }^{2}$ \\ 1,2 Jurusan Ilmu Pemerintahan, Fakultas Ilmu Sosial Dan Ilmu Politik, Universitas Riau \\ Pekanbaru, Indonesia \\ Adlinoke@gmail.com
}

\begin{abstract}
ABSTRACK
The existence of adat institutions is recognized in the government system of the Unitary Republic of Indonesia. This includes traditional institutions that exist at the village level. In the regulation of the Minister of Home Affairs No. 18 of 2018 concerning Village Social Institutions and Village Adat Institutions, it is stated that the village customary institution or other designation is an institution that carries out the customs function and forms part of the original arrangement of the village that grows and develops on the initiative of the village community. Singingi River Basin Formerly a kingdom called the Singingi kingdom which has a complete structure down to the country or village under its shelter. An interesting phenomenon is that the king in the Singingi River Basin is held by two people who have the title Datuk Khalifah. This study aims to explain history so that the emergence of two kings in the Singingi sect and describe the structure of traditional institutions in the country under its aegis. The theory used is the Geneological-Territorial customary law community alliance theory. The study used a qualitative method with the documentation method and was strengthened by conducting interviews with 8 informants and then analyzed through data triangulation. The research findings show that the Singingi river basin was formed based on geneological and territorial ties. The structure of adat institutions in each country modeled on the structure of adat institutions at the center of the kingdom, although there were variations in the application in each country.
\end{abstract}

Kata Kunci: Customary Institutions, Singingi

\section{PENDAHULUAN \\ Keberadaan Lembaga adat di akui} dalam sistem pemerintahan Negara Kesatuan Republik Indonesia. Termasuk di dalamnya Lembaga adat yang eksis di level desa. Dalam peraturan Menteri Dalam Negeri Nomor 18 Tahun 2018 Tentang Lembaga Kemasyarakatan Desa dan Lembaga Adat Desa dinayatkan bahwa lembaga adat desa atau sebutan lainnya adalah lembaga yang menjalankan fungsi adat istiadat dan menjadi bagian susunan asli desa yang tumbuh dan berkembang atas prakarsa masyarakat desa. Bahkan dalam Pasal 9 ayat 1 peraturan tersebut dinyatakan bahwa Lembaga Adat Desa dapat dibentuk oleh pemerintah desa dan masyarakat desa. Ini Artinya Lembaga adat desa dianggap sebagai lembaga yang penting dalam menunjang kemajuan desa.

Struktur lembaga adat di desa desa di aliran sungai Singingi sebetulnya sudah lengkap dan masih ada dan terus dilestarikan. Daerah aliran sungai Singingi dahulunya terdapat sebuah kerajaan, yaitu kerajaan Singingi yang lengkap struktur 
NAKHODA:

JURNAL

ILMU PEMERINTAHAN
NAKHODA: JURNAL ILMU PEMERINTAHAN

Edisi Januari - Juni 2019 Volume: 18 Nomor: 1

ISSN : 1829-5827 | E-ISSN : 2656-5277

DOI : https://doi.org/10.35967/jipn

https://nakhoda.ejournal.unri.ac.id/index.php/JIPN lembaganya dan menjadi kerajaan yang mandiri pada tahun $1651 \mathrm{M}$. setelah diserahkan kewenangan kekuasaan oleh penguasa kerajaan Pagaruyung kepada 2 orang pemimpin Singingi yang baru yaitu Datuk Bendaharo dan Datuk Jelo Sutan, yang dilengkapi dengan pemberian cap kerajaan bertuliskan huruf Arab Melayu. Bahkan di masa penjajahan belanda, struktur lembaga adat di aliran sungai Singingi tetap diakui, dibuktikan dengan pengakuan kekuasaan Belanda di Singingi ditanda tangani oleh struktur lembaga adat kerajaan Singingi tahun 1907 . Pada masa Belanda juga salah seorang raja di Singingi, yaitu Datuk Khalifah Moh Sirih yang bergelar datuk Bendaharo diangkat sebagai penguasa di daerah otonom Singingi tahun 1919 . Dalam catatan Wan Ghalib, Kerajaan Singingi adalah satu dari 14 kerajaan yang ada di Riau yang dipimpin oleh dua orang raja yang bergelar Dt Jelo Sutan dan Dt Bendaharo . Namun demikian setelah Indonesia merdeka, fungsi lembaga adat ini terpinggirkan dalam sistem pemerintahan nasional. Akibat peminggiran tersebut struktur lembaga adat masih bertahan namun minim fungsi. Oleh karena itu tulisan ini mencoba mengungkap sejarah penyusunan lembaga adat Singingi dan bagaimana strukturnya yang tersebar ke negeri di dalam naungannya?

\section{KERANGKA TEORI}

Istilah masyarakat hukum adat lahir dari bentuk kategori pengelompokkan masyarakat yang diajarkan oleh pemikir hukum adat Cornellis van Vollenhoven. Kategori kelompok sosial itu yang kemudian dikenal dengan bentuk masyarakat hukum (rechtgemeenschappen) adalah masyarakat yang seluruh anggota komunitasnya terikat sebagai satu kesatuan oleh hukum yang dipakai. Bila hukum yang dipakai itu adalah hukum adat, maka kesatuan masyarakat ini disebut masyarakat hukum adat ( adat rechtgemeenschappen $)^{1}$

Mengutip Ter Haar, Ferry Aries Suranta menyatakan masyarakat hukum atau persekutuan hukum adat sebagian besar masih tetap hidup dengan hukum adatnya masing-masing berdasarkan ikatan teritorial atau berdasarkan geneologis dan / atau campuran anatar keduanya, yaitu yang bersifat GenelogisTerritorial $^{2}$. Selanjutnya Suranta mengutip Van Dijk menjelaskan bahwa persekutuan hukum teritorial dapat dibedakan dalam tiga macam ${ }^{3}$ yaitu :

1) Persekutuan Desa;

2) Persekutuan Daerah;

3) Perserikatan Desa.

Termasuk persekutuan daerah adalah seperti kesatuan masyarakat "Nagari" di Minang Kabau, di masa lampau yang merupakan suatu daerah kediaman bersama dan menguasai tanah hak ulayat yang terdiri dari beberapa dusun atau Kampung dengan satu pusat pemerintahan bersama ${ }^{4}$.

Subari dkk mengemukakan ada dua faktor yang mendukung terbentuknya persekutuan masyarakat hukum, yaitu faktor keturunan (geneologis) dan faktor daerah (territorial). Kedua faktor tersebut kemudian membentuk 3 persekutuan hukum, yaitu persekutuan hukum Geneologis, persekutuan hukum Territorial dan Persekutuan Hukum Geneologis-Territorial.
1) Persekutuan
Geneologis. Adalah persekutuan hukum 
yang warganya terikat satu sama lain dalam persekutuan karena persamaan keturunan sesungguhnya atau dalam anggapan saja;

2) Persekutuan hukum Territorial. Adalah Persekutuan hukum yang warganya terikat satu sama lain dalam persekutuan karena mereka menetap bersama dalam suatu daerah.

3) Persekutuan Geneologis Territorial. Adalah Persekutuan hukum yang warganya terikat satu sama lain dalam persekutuan oleh ikatan keturunan dan juga ikatan daerah tempat tinggal ${ }^{5}$.

Dalam Bab IX Undang Undang Republik Indonesia Nomor 41 Tahun 1999 tentang Kehutanan sebutkan bahwa masyarakat hukum adat di akui keberadaannya dengan kriteria antara lain ${ }^{6}$ :

a) Masyarakatnya masih dalam bentuk Paguyuban

b) Ada kelembagaan dalam bentuk perangkat penguasa adatnya

c) Ada wilayah hukum adat yang jelas

d) Ada pranata hukum, khususnya peradilan adat yang masih ditaati dan

e) Masih melakukan pemungutan hasil hutan diwilayah hutan sekitarnya untuk pemenuhan kehidupan sehari-hari.

Subari dkk sebuah persekutuan dinamakan persekutuan hukum adat harus memenuhi kriteria :

a) Kumpulan orang dalam persekutuan tersebut bersifat tetap;

b) Mempunyai pemerintahan dan kekuasaan sendiri; c) Mempunyai kekayaan sendiri;

d) Persekutuan tersebut bertindak sebagai kesatuan lahir dan batin, ke dalam dan ke luar sebagai pendukung hak dan kewajiban? ${ }^{7}$

Berdasarkan uraian tersebut,disimpulkan bahwa kelembagaan adat atau perangkat penguasa adat merupakan bagian penting dalam sebuah masyarakat hukum adat.

Musyawarah atau rapat merupakan forum tertinggi dalam masyarakat adat dalam memilih pemimpin adat maupun masalah penting lainnya yang dihadapi masyarakat adat. Dalam pemilihan ataupun pengangkatan kepala adat atau pemangku adat beserta pembantunya misalnya, unsur mutlak adalah didasarkan keturunannya atau turun temurun dan ini semua hampir terjadi diseluruh hukum adat Indonesia, tetapi kemudian ada pula yang dipilih berdasarkan kesepakatan atau hasil musyawarah dari masyarakat hukum adat setempat. Biasanya orang orang tertua, terkemuka dan mempunyai pengaruh serta dianggap mampu menjadi kepala adat yang kemudian dipilih menjadi pemimpin mereka ${ }^{8}$. Kepala persekutuan sebagai puncak kekuasaan berfungsi sebagai pamong, sebagai pemimpin, sebagai polisi, dan juga hakim. Berdasarkan fungsi yang disebutkan di atas, maka tugasnya dapat dibedakan kepada tugas pemeliharaan dan tugas pembetulan hukum ( preventif dan refresif $)^{9}$. Menurut hukum adat pengganti kepala pesukuan diangkat, diakui dan dipilih atas dasar pewarisan dengan pemilihan dalam musyawarah. Dalam arti ahli waris pertama dari kepala pesukuan lama mendapat hak diurutan pertama untuk menduduki jabatan pengganti. Akan tetapi apabila ahli waris 
pertama itu dengan sesuatu alasan dianggap tidak cakap atau tidak patut seperti cacat jasmani dan rohani, maka ia dapat dilalui dan diganti dengan ahli waris berikutnya yang dianggap cakap memimpin persekutuan ${ }^{10}$.

\section{METODE PENELITIAN}

Penelitian ini menggunakan metode kualitatif, teknik pengumpulan data dilakukan dengan metode dokumentasi dan wawancara 8 informan terkait. Analisa data dilaksanakan bersamaan dengan wawancara serta analisa dokumen dengan cara mengumpulkan data mereduksi data, serta melakukan triangulasi data yang kemudian ditampilkan dalam laporan penelitian.

\section{HASIL DAN PEMBAHASAN}

\section{a. Batas Wilayah Adat}

Batas-batas wilayah Singingi menurut keadaan semenjak purbakala sampai dengan sekarang tetap seperti semula $^{11}$, yaitu ::

1. Ke Timur dengan wilayah Kampar Kiri ( hingga Sei Nopan $5 \mathrm{~km}$ di Hilir Tanjung Pauh);

2. Ke utara dengan Subayang wilayah Kampar Kiri hingga Sianik Putih;

3. Ke barat dengan negeri Sumpur Kudus hingga bukit Penyabungan;

4. Ke selatan dengan wilayah Kuantan Hulu ( Teluk Kuantan) hingga Tobek Sigadobang, Kompe Buahan Batu dan Bukit Padang Terbakar di Mudik Ulo. Wilayah adat Singingi ini merupakan gabungan ulayat adat dari dua Kelompok suku Piliang Nan Limo (Piliang Yang Lima) dan Melayu Nan Ompek ( Melayu yang empat $)^{12}$ sebagai berikut :

1. Piliang Nan Limo :

- Datuk Bandaro, datuk Maharajo beserta datuk Sinaro Nan Putih keduanya dalam kandungan Datuk Bandaro juga, sebelah timur berbatas dengan Sungai Ruang (Durian Daun) dengan Datuk Mangkuto Sinaro, ke barat dengan Datuk Bandaro Kali di Rimbo Pematang Kilangan, ke Selatan Hingga Bukit Penyabungan batas Sumpur Kudus dengan Negeri Pangkalan Indarung;

- Datuk Bandaro kali, Ke sebelah barat berbatas dengan Datuk Bandaro di Rimbo Pematang Kilangan dan ke Utara hingga Sianik Putih Subayang;

- Datuk Besar ulayatnya terletak dalam kandungan Datuk Bandaro yaitu Sungai Sepuh.

2. Melayu Nan Ompek:

- Datuk Jelo Sutan

- Datuk Mangkuto Sinaro

- Datuk Sinyato Mempunyai ulayat yang sama yaitu sebelah timur dari sungai Tikalak Godang terus ke Sungai Nopan, Sebelah Barat dari bukit Buluh Rampai sampai ke Sianik Putih Subayang, Sebelah Selatan dengan 
Tobek Sigadobang Kompe Buahan Batu dan terus ke Bukit Padang terbakar, dari Bukit Penyabungan batas Sumpur Kudus Sumatera Barat.

Berdasarkan uraian di atas dapat diketahui bahwa kerajaan Singingi termasuk persekutuan daerah yang merupakan gabungan dari wilayah milik pesukuan yang menetap di kawasan tertentu. Disisi lain juga dapat diketahui bahwa salah satu faktor yang menyebabkan wujud dan eksisnya kerajaan singingi adalah masyarakatnya disatukan berdasarkan ikatan kesamaan daeran tempat tinggal, kesatuan masyarakat hukum territorial.

\section{b. Sejarah Terbentuknya Lembaga Adat Singingi}

Penyusunan Lembaga Adat di Aliran Sungai Singingi dilakukan dengan musyawarah. Ini artinya sesuai dengan teori Van Dijk yang mengemukakan bahwa pemilihan pemimpin adat secara umum dilakukan melalui musyawarah dan dipilih yang tertua dan terkemuka dalam kelompok tersebut. Menurut Tombo Adat Rantau Singingi, penyusunan pemerintah adat dimulai dengan musyawarah antara datuk Bandaro di Koto Intuk dengan Datuk Jelo Sutan, yang kemudian dilanjutkan dengan musyawarah yang melibatkan seluruh unsur di wilayah aliran sungai Singingi ${ }^{13}$. Kerajaan Singingi dipimpin oleh 2 orang, yang bergelar datuk khalifah, yang dikenal dengan sebutan Datuk Nan Baduo yaitu Datuk Bendaharo dari Suku Piliang dan Datuk Jelo Sutan dari suku Melayu. Lokasi ibu kota kerajaan disebut tanah kerajaan merupakan gabungan 3 desa, yaitu Pulau Padang sebagai kapalo Koto ( kepala negeri), Kebun Lado ekor koto ( ekor negeri) dan Muara Lembu ( Ranah Tanjung Bungo) sebagai pusat kota kerajaan ${ }^{14}$. Wilayahnya meliputi 9 kampung, yaitu Pangkalan Indarung, Pulau Padang, Muara Lembu, Kebun lado, Petai, Koto Baru, Pulau Petai/ Sungai Paku, Tanjung Pauh dan Logas ${ }^{15}$. Terbentuk struktur lembaga adat di daerah Aliran Sungai Singingi, yang menjelma menjadi kerajaan Singingi merupakan kesepakatan para datuk yang merupakan pemuka masing masing koto (negeri) dengan suku suku tertentu yang dahulunya bermukim di Aliran Sungai Singingi, yang dirinci sebagai berikut ${ }^{16}$ :

1) Koto Muaro Simpang yang bernama Muara Lembu Sekarang adalah Koto Mangkuto Sinaro keturunan Rantau Kuantan pecahan Datuk Mudo Bisai, menjadi suku Melayu;

2) Koto Intuk, sekarang lokasinya termasuk dalam wilayah desa Pulau Padang, Pemimpinnya Datuk Bandaro, Datuk Sinaro nan Putih beserta Datuk Majo, keturunan alam minang Kabau Pagaruyung, menjadi suku Piliang;

3) Koto Tinggi Tasam, sekarang lokasinya termasuk dalam wilayah desa Pulau Padang, Pemimpinnya Datuk Bandaro Kali, keturunan alam minang Kabau Pagaruyung turun ke Subayang, menetap di Kawasan Tasam, menjadi suku Bendang;

4) Koto Cinatin, sekarang lokasinya termasuk dalam 
wilayah desa Kebun Lado, Pemimpinnya Datuk Sinyato keturunan dari tanah Johor, menurut jalan dan singgah di koto Cinatin, menjadi Suku Melayu;

5) Koto Pingiai di Sungai Tapi , sekarang lokasinya termasuk dalam wilayah desa Petai, Pemimpinnya Datuk Jelo Sutan keturunan tanah Johor menurut jalan dan singgah di Koto Pingiai, menjadi suku Melayu;

6) Koto Sinabuh, sekarang lokasinya termasuk dalam wilayah desa Tanjung Pauh, pemimpinnya Datuk Besar keturunan Kuntu Subayang, singgah di Sinabuh dan menetap di Sinabuh, menjadi suku Piabadar;

7) Koto Degi, sekarang lokasinya termasuk dalam wilayah desa Sungai Paku, pemimpinnya datuk Maharajo Garang keturunan dari alam minang Kabau Pagaruyung turun ke Rantau Subayang, singgah dan menetap di koto Degi, menjadi suku Piabadar.

Berdasarkan uraian di atas dapat disimpulkan bahwa penyusunan lembaga adat dilakukan secara musyawarah para datuk yang mereka disatukan oleh faktor faktor geneologis, yaitu ikatan keturunan yang dulunya menetap pada suatu daerah tertentu di aliran Sungai Singingi.

\section{c. Susunan Lembaga Adat}

Struktur lembaga adat di di daerah aliran Singingi dipimpin oleh dua orang penghulu pucuk yang bergelar datuk khalifah yang lazim dikenal dengan Datuk Nan Baduo. struktur dibawahnya langsung adalah 7 orang datuk penghulu, yang lazim dikenal dengan Datuk Nan batujuah dan Datuk penghulu di masing masing negeri/ koto. Penyusunan Struktur Lembaga Adat disusun mempertimbangkan wakil dari kelompok suku Melayu dan wakil kelompok Suku Piliang, dikenal dengan istilah Melayu nan ompek ( Melayu yang Empat), Piliang nan Limo ( Piliang Yang lima). Peresmian lembaga adat ini ditandai dengan pemotongan kerbau yang dinamakan Si lenggang Tanduk di Pulau Galanggang di hilir koto Muaro Simpang ( Muara Lembu). Rincian Suku berdasarkan kelompok suku Piliang dan Melayu berikut pemimpinnya diuraikan sebagai berikut ${ }^{17}$ :

1) Suku Piliang

Dalam suku Piliang di angkat yang sebagai pemimpin adalah Datuk Bandaro menjadi Datuk Nan baduo. Penghulu lainnya menjadi bagian dari Datuk Nan Batujuah. Yaitu :

a) Datuk Sinaro Nan Putih dari penghulu dari suku Piliang;

b) Datuk Besar penghulu dari suku Piabadar;

c) Datuk Bandaro Kali penghulu suku Bendang;

d) Datuk Maharajo Garang dari suku Piabadar.

2) Suku Melayu

Dalam suku Melayu yang diangkat sebagai pemimpin adalah datuk Jelo Sutan menjadi Datuk nan Baduo, penghulu lainnya sebagai bagian dari Datuk Nan Batujuah. Yaitu :

a) Datuk Mangkuto Sinaro; 
NAKHODA:

JURNAL

ILMU PEMERINTAHAN
NAKHODA: JURNAL ILMU PEMERINTAHAN

Edisi Januari - Juni 2019 Volume: 18 Nomor: 1

ISSN : 1829-5827 | E-ISSN : 2656-5277

DOI : https://doi.org/10.35967/jipn

https://nakhoda.ejournal.unri.ac.id/index.php/JIPN b) Datuk Sinyato;

c) Datuk Simajo Lelo.

Dengan demikian dapat dipahami bahwa adanya dua orang raja di Singingi merupakan wakil dari kelompok suku yang melayu nan ompek dan dari kelompok suku yang piliang nan limo.

Tata hubungan Datuk Nan Baduo dengan Datuk Nan Batujuah ${ }^{18}$ sebagai berikut :

1. Datuk Nan Baduo yaitu Datuk Bandaro dan Datuk Jelo Sutan adalah pimpinan utama pemegang kendali tertinggi adat wilayah Singingi.

2. Datuk Nan Batujuah yaitu Datuk Bandaro Kali, Datuk Sinaro Nan Putih, Datuk Besar, Datuk Maharajo Garang, Datuk Mangkuto Sinaro, Datuk Sinyato, Datuk Simajo Lelo adalah dewan pimpinan adat wilayah Singingi.

3. Datuk Nan Baduo, Datuk Nan Batujuah mempunyai kewajiban dan kewenangan atas pembinaan dan pengawasan ninik mamak pemangku adat dan rakyat cucu kemenakan.

4. Datuk Nan Baduo dan datuk Nan Batujuah mempunyai kewajiban dan kewenangan menurut adat atas pembinaan hutan tanah ulayat suku dan ulayat wilayah negeri;

5. Datuk Nan Naduo, datuk Nan Batujuah mempunyai kewajiban dan kewenangan menurut adat menyelesaikan sengketa, perselisihan sempadan atau batas ulayat.

6. Proses pengangkatan datuk Nan Baduo, tetap diusulkan dari suku asal yang dipandang cakap dan mampu, diajukan ke dewan datuk Nan Batujuah untuk mendapat pertimbangan diterima atau ditolak;

7. Proses pengangkatan datuk Nan Baduo dilakukan oleh dewan Datuk Nan Batujuah dibawah koordinasi datuk Bandaro Kali menurut adat di hadiri seluruh Penghulu dan Monti Se Rantau Singingi;

8. Pemegang daulat datuk Nan Baduo dapat diberhentikan oleh datuk Nan Batujuah dan penghulu penghulu atas desakan masyarakat adat, apabila terjadi ketidakyakinan pandangan atau ketidak pedulian atas pelaksanaan fungsi dan tugasnya dan kondisi uzur yang dipandang tidak mampu lagi memangku daulat yang dipercayakan kepadanya. Rantau indak tataulangi, Nagori indak takanano.

Selanjutnya di bentuk lah negeri yang berbeda dengan koto koto sebelumnya dan di susun juga perangkat adat di masing masing negeri atau koto yang dipimpin oleh dua khalifah di setiap koto ( negeri), yang disebut khalifah duo sakoto sebagai perwakilan datuk Nan Baduo. Menurut pepatah adat kebesaran penghulu di masing-masing negeri " $b a$ mamak kepada Datuk Nan Ba Tujuah, Ba Rajo kepada Datuk Nan Baduo di tanah kerajaan Muara Lembu"19. Ini artinya penghulu negeri memiliki atasan langsung ke 7 orang penghulu kerajaan yaitu Datuk Nan Batujuah, selanjutnya 7 orang penghulu kerajaan atasan langsungnya adalah Datuk Nan Baduo sebagai pimpinan 
NAKHODA:

JURNAL

ILMU PEMERINTAHAN
NAKHODA: JURNAL ILMU PEMERINTAHAN

Edisi Januari - Juni 2019 Volume: 18 Nomor: 1

ISSN : 1829-5827 | E-ISSN : 2656-5277

DOI : https://doi.org/10.35967/jipn

https://nakhoda.ejournal.unri.ac.id/index.php/JIPN pucuk kerajaan. Perangkat adat tersebut di rinci sebagai berikut ${ }^{20}$ :

1. Tanjung Pauh, dengan 5 penghulu, yaitu :

1) Datuk Tumanggung ( Datuk Khalifah wakil suku Domo)

2) Datuk Jelo Sutan ( Datuk Khalifah wakil suku Melayu)

3) Datuk payung Putih

4) Datuk bendaro Putih

5) Datuk Bendaro Sati

2. Pulau Petai, sekarang Sungai Paku dengan 4 Penghulu, yaitu :

1) Datuk payung Putih ( Datuk Khalifah wakil suku Melayu)

2) Datuk Muwun ( Datuk Khalifah wakil suku Domo)

3) Datuk Melintang Kampar

4) Datuk Laksamano

3. Koto Baru, dengan 5 Penghulunya, yaitu :

1) Datuk Bandaro Hitam ( Datuk Khalifah wakil suku Melayu)

2) Datuk Temenggung ( Datuk Khalifah wakil suku Melayu Tonga)

3) Datuk Bandaro Raja

4) Datuk Sinyato

5) Datuk Bendaro Sutan

4. Petai, dengan 4 Penghulunya, yaitu

1) Datuk Datuk Bandaro Kayo ( Datuk Khalifah wakil Piliang)

2) Datuk Sati ( Datuk Khalifah wakil Suku Melayu)

3) Datuk Bandaro Mudo

4) Datuk Sinego

5. Pangkalan Indarung, dengan 5 Penghulunya :

1) Datuk Bandaro ( Datuk Khalifah wakil suku Piliang)
2) Datuk Sutan Penghulu ( Datuk Khalifah wakil suku Melayu)

3) Datuk Rajo Melayu

4) Datuk Lelo Mangkuto

5) Datuk Sinyato

Adapun struktur lembaga adat di Logas berbeda dengan negeri lainnya. Hal ini tidak bisa dilepaskan dari sejarah perang saudara di Singingi. Setelah Datuk Nan Baduo mendapat penyerahan amanat dari Pagaruyung tahun 1651, datang lah Tuanku Nan Kuniang kemenakan Tuanku Rajo Bayang yang ingin menjadi Raja di Singingi, yang ditolak oleh Datuk Nan Baduo. Kemudian Tuanku Nan Kuniang melakukan perlawanan dengan membuat basis pertahanan di Logas. Selain dibantu orang Logas, dia minta juga bantuan ke Jake dan Mudik Ulo untuk menyerang dan menaklukkan kerajaan Singingi. Datuk nan Baduo beserta pasukannya dibantu pasukan dari Subayang cepat mengambil tindakan dan menyerang Logas maka terjadilah pertempuran di sana. Perang Logas dimenangkan Datuk Nan Baduo dan Tuanku nan Kuniang melarikan diri ke Kuantan $^{21}$. Setelah kejadian itulah di Logas disusun lembaga adat, dengan status Luhak dengan dipimpin seorang Penghulu utama yang sehari hari disebut Datuk Godang, yang dimasa Belanda disebut Khalifah Nan Tunggal ${ }^{22}$. Penghulu di Logas, ada 5 yaitu:

1) Datuk Godang

2) Datuk Temenggung

3) Datuk Rajo Penghulu

4) Datuk Paduko

5) Datuk Panghulu Dagang/ Datuk Siak Gagah

Semua penghulu di Logas termasuk dalam kandungan Datuk Jelo Sutan penghulu pucuk Suku Melayu antau Singingi ${ }^{23}$. 
NAKHODA:

JURNAL

ILMU PEMERINTAHAN
NAKHODA: JURNAL ILMU PEMERINTAHAN

Edisi Januari - Juni 2019 Volume: 18 Nomor: 1

ISSN : 1829-5827 | E-ISSN : 2656-5277

DOI : https://doi.org/10.35967/jipn

https://nakhoda.ejournal.unri.ac.id/index.php/JIPN
Tata Hubungan kedudukan Datuk Nan Batujuah sebagai dewan pimpinan adat dengan Khalifah Duo Sakoto, penghulu, monti dan dubalang diuraikan sebagai berikut ${ }^{24}$ :

1) Melakukan pembinaan dan pengawasan internal terhadap ninik mamak pemangku adat di negeri negeri termasuk monti dan dubalang serta cucu kemanakan;

2) Melakukan pembinaan teknis terhadap pembawaan dan pemakaian adat dalam setiap prosesi kegiatan adat yang dilakukan ninik mamak meliputi susunan bahasa dalam berkata-kata, jemput antar cucu kemenakan, kegiatan acara adat, musyawarah dan lain-lain;

3) Dalam pelaksanaan kegiatan forum yang bersifat prinsip dan urgen setiap suku dan negeri, penghulu negeri, penghulu khalifah duo sakoto senantiasa melakukan konsultasi dengan datuk nan Batujuah;

4) Dewan pimpinan adat datuk nan Batujuah menyampaikan informasi kepada datuk nan baduo sebagai penghulu pucuk, hal-hal yang berhubungan dengan informasi, laporan, pelaksanaan kegiatan, dan permasalahan di tingkat negeri atas permintaan dan laporan datuk khalifah duo sakoto, atau penghulu lainnya yang mendapat kewenangan dari Datuk khalifah duo sakoto;

5) Dalam memenuhi permintaan dan mempertimbangkan hal hal yang bersifat prinsip, datuk nan Batujuah melakukan komunikasi dan koordinasi sesama penghulu datuk nan Batujuah dan bila dipandang perlu langsung menghadirkan datuk Nan Baduo.

\section{KESIMPULAN}

Masyarakat hukum adat daerah aliran Sungai Singingi merupakan persekutuan daerah disatukan oleh faktor Geneologis Territorial yang penyusunan lembaga adatnya dilakukan secara musyawarah. Lembaga adat dipimpin dua orang raja penghulu pucuk di bantu 7 orang penghulu dan di setiap desa terdapat 2 penghulu pucuk sebagai perwakilan dari dua orang raja di pusat kerajaan Singingi, yang diambil 1 orang dari kelompok suku piliang dan 1 orang dari kelompok suku Melayu, kecuali Logas yang dipimpin seorang penghulu pucuk

\section{DAFTAR PUSTAKA}

Arizona, Yance (peny). 2010. Antara teks dan konteks : Dinamika Pengakuan Hukum terhadap Hak masyarakat Adat atas Sumber daya Alam di Indonesia. Jakarta : Huma.

Dijk,Van. 1982. Pengantar Hukum Adat Indonesia. Bandung : Mandar Maju

Halkis. 2006. Revitalisasi tanah Ulayat : Tantangan dan Peluang. Pekanbaru: Yayasan Pusaka Riau.

Oemala, Zulbakri. 2019. Tambo Alam dan Adat : Sejarah Negeri Adat, Pemerintahan, dan Budaya Antau Singingi. Dokumen belum di terbitkan.

Subari, Albar S. dkk.2010. Pokok Pokok Hukum Adat. Palembang : 
Universitas Sriwijaya..

Suranta, Ferry Aries. 2011. Penggunaan Lahan Hak Ulayat Dalam Investasi Sumber Daya Alam Pertambangan di Indonesia. Depok : Gramata Publishing.

\section{Dokumen}

Ikatan Keluarga Singingi Rengat. 1983. Tombo Adat Rantau Singingi yang ditulis 1957. Rengat

Overeenkomsten met inlandsche Vorsten in den Oost-indischen Archipel

\section{(312.3)}

(https://repository.overheid.nl/frbr/s gd/19091910/0000348997/1/pdf/S GD_19091910_0001292.pdf)

Overeenkomsten met inlandsche Zelfbestuunders in Nederlandschindie

(https://repository.overheid.nl/frbr/s gd/19091910/0000348997/1/pdf/S GD_19091910_0001292.pdf

\section{ENDNOTE}

\footnotetext{
${ }^{1}$ Yance Arizona (peny). 2010. Antara teks dan konteks : Dinamika Pengakuan Hukum terhadap Hak masyarakat Adat atas Sumber daya Alam di Indonesia. Jakarta : Huma., 4

${ }^{2}$ Ferry Aries Suranta.2011. Penggunaan Lahan Hak Ulayat Dalam Investasi Sumber Daya Alam

Pertambangan di Indonesia. Depok : Gramata Publishing.,97

${ }^{3}$ Ibid.

${ }^{4}$ Ibid.

${ }^{5}$ Albar S. Subari dkk.2010. Pokok Pokok Hukum Adat. Palembang : Universitas Sriwijaya., 25-26.

${ }^{6}$ Yance Arizona (peny). 2010. Op.Cit.., 29.

${ }^{7}$ Albar S. Subari dkk.2010. Op.Cit., 22.

${ }^{8}$ Van Dijk. 1982. Pengantar Hukum Adat Indonesia. Bandung : Mandar Maju., 34.

${ }^{9}$ Albar S.Subari. Op.Cit., 24.

${ }^{10}$ Ibid., 23.

${ }^{11}$ Ikatan Keluarga Singingi Rengat. 1983. Tombo Adat Rantau Singingi yang ditulis 1957. Rengat, 2.

${ }^{12}$ Ibid., 10-11.

${ }^{13}$ Ikatan Keluarga Singingi Rengat. 1983. Op. Cit.2-3

${ }^{14}$ Rifaini Chatib. 1999. Tombo Adat Rantau Singingi. Muara Lembu., 7

${ }^{15}$ Ikatan Keluarga Singingi Rengat. 1983. Op. Cit., 5

${ }^{16}$ Ibid., 3.

${ }^{17}$ Ikatan Keluarga Singingi Rengat. 1983. Tombo Adat Rantau Singingi yang ditulis 1957. Rengat, 56.

${ }^{18}$ Zoelbakri Oemala (2007). Adat Kemasyarakatan Rantau Singingi. Muara Lembu : Lembaga Adat

Antau Singingi., 21-22

${ }^{19}$ Ikatan Keluarga Singingi Rengat. Op.Cit., 6.

${ }^{20}$ Ibid., 6-7.

${ }^{21}$ Halkis Op.Cit., 83-84.

${ }^{22}$ Zulbakri Oemala. Op.Cit., 11.

${ }^{23}$ Ikatan Keluarga Singingi Rengat. Op.Cit., 7.

${ }^{24}$ Zulbakri Oemala. Op.Cit., 22-23.
} 